\title{
Management strategy of the Marind Cultural Arts Festival as breakthrough innovations for improving tourism appeal in Merauke, Papua
}

\author{
Fitriani \\ Faculty of Social Science and \\ Political Science, \\ Musamus University \\ Merauke, Papua Indonesia \\ (fitriani310878@gmail.com)
}

\author{
Dr. Ida Hayu Dwimawanti \\ Faculty of Social Science and \\ Political Science, \\ Dipenogoro University \\ Semarang, Cntral of Java \\ (prodidap@gmail.com)
}

\author{
Edoardus E. Maturbongs \\ Faculty of Social Science and \\ Political Science, \\ Musamus University \\ Merauke, Papua Indonesia \\ (edoms.unmus@yahoo.co.id)
}

\begin{abstract}
Merauke is a district area of Marind ethnic shelter life, the expansion of Papua especially in Merauke, making the young generation forget their identity. Government's efforts to preserve Marind cultural ethnic is by holding the Ndambu Festival for 3 years, nonetheless the lack information and the distance activity place so that these activities do not impact. This study describes the innovation implementation of Marind cultural arts festival, this researcher uses descriptive qualitative methods focus on management strategy of this festival, starting from planning up to evaluation. Implementation of management strategy produces the right success of the festival activities, and expected this activity can take place annually in the long term and able to increase tourism and economy appeal in Merauke and undertook to preserve Marind ethnic culture art.
\end{abstract}

Keywords—Management; Marind Festival; Papua

\section{INTRODUCTION}

Ndambu words means compete healthily. This ritual formerly held in order to dilute the disputes between clans or villages and the district on the Kimaam Island, bordering with Papua New Guinea, and the Arafura Sea. This Island is separate with Merauke land, located in south Papua. Ndambu is one of the hereditary ritual displays of agriculture celebrations held when their important family member pass away and commemorate their deceased. The core values of the ceremony festival is have to work hard, don't be lazy. Planting is not just for the festival but to fulfill their family necessities. However for three years, this festival has done have yet to find a good pattern organization so that it could not only known Ndambu in Papua but also known nationally and internationally. This Festival also involves a lot of people up to the thousands, doing a variety of race and culture, and spend the funds Income Budget Finance Region around 3.5 billion. The biggest obstacle of unsuccessful festival is transportation and the lack information, then the researcher interest to take research on the management strategy of the Marind cultural arts festival as breakthrough innovations for improving tourism appeal in Merauke, Papua.

\section{RESEARCH METHOD}

The research uses participatory methods, qualitative research approaches with descriptive. Where the researchers directly involved in the Marind cultural arts festival activities, namely by observing, interviewing, provide inputs, analyzing, describing and evaluating.

\section{RESUlt AND DiscUSSION}

The Festival is an event celebrated by the community and usually centered on some aspect of the characteristics of the community or tradition. The Festival is the focus on the topic of culture seeks to inform owned members of the public over tradition. Cultural Arts Festival usually mixed program which may include culture, traditions, music, literature, comedy, children's entertainment, science, and others presented in a certain period. Artists participating in the exhibition are the most important part of the festival. Cultural Arts Festival Marind 2016 conducted by an art community, with funding from the local government in Merauke district is a new breakthrough for the local government, because for the first time a community entrusted to carry out the festival. The festival activity truly has been planned from the beginning by 2015 in the sysop community work plan. Then do the formation of the Committee, with select members who are very competent in the sections that are created, as well as understand the arts and concerned with cultural sustainability Marind. Support human resources committed to these officials in the main activities of the festival passes. This results of Committee's meeting discussion of this festival determine themes and sub themes activities tailored to Merauke motto of (expected to be a long-term reference), various contents festival as follow (Merauke photo exhibition once-now, the photo art exhibition and Marind dance performance both of -moderncontemporary, exhibition booths of the share element of the art and culture in Papua, Marind tifa culture book exhibition, book launch of merauke in the photos), adjacent to the implementation date bases on this city anniversary (community bustling festive moment), the place of execution in a huge building is set in the middle of the city (make it easier to transport), as well as implemented just 1 day from morning till 
night (use of funds is not great). Since the mid-2015 community (the Committee) has already done in the coordination form approaches by the perpetrators of art from particular various regions in Merauke, Papua to get involved participate in such activities.

Similarly, service-relates service and youth organizations as well as other independent organizations for support in moral and material for the festival. The Government officially has been designing society area to carry out this festival as an extension form of Marind cultural arts preservation. The festival promotion is done via email, websites, invitations, facebook, Republic Indonesia Radio known as RRI, and banners from September 2015, making it an echo festival is already felt by society in Papua region. Despite limited funds, with the support, cooperation and a commitment from the Committee, the artist participant, organization service, other organizations have created the successful implementation of the Marind cultural arts festival. This is visible from the enthusiastic artists from inside and outside from Merauke is present and become participants in this festival, society visiting that so many from morning to night closures, even bases on society interview, the most of them want this festival more than 1 day, because a lot of the knowledge they get for their selves or for children, in addition to the abundance of art sold results illustrate the buying and selling process and the economic impact for society perpetrator art. Evaluation and accountability activities carried out by collecting the entire festival organizers and the local government in Merauke, openly community (Committee) receives many suggestions and shortcomings that must be rectified in the next year so that it could be more successful and this schedule as an annual event by entering the activities kinds that are different from monotonous and packed so there is more interesting and visible ideas originality.

Managing strategic of Marind arts cultural festival activities is done by the society above is statement reflection of Fred r. David (2008:5) about management strategy is the art and science of formulating, implementing, and evaluating crossdecision functions that allow the organization can reach its destination. Management strategy is more emphasis on strategic decision-making. Strategic decisions relates whole organization in future for long term The purpose of the management strategy is to exploit new opportunities and create a different future, long-term planning and trying to optimize the trend today for the future. Stages in strategic management are strategic formulation, implementation and strategic evaluation of location.
This means that society has done festival planning (Rob Harris and Johnny Allen, 2002) which consists of strategic planning (vision, mission, objectives, goals, strategies), and the planning operational (finance, human resource, marketing, fundraising, programming, unmarked, exhibition, logistic management, attendance, transportation, safety, communications location). The process undertaken by this society can be called by the festival management, namely full service event management form, production, and consultants who are responsible for the production and management creation in various festivals and events. With this team often behind-the-scenes running the event, involve in the planning and execution the event. Build your brand, marketing strategy and communications. The planning process and this event coordinating is commonly refer as event planning and may include budgeting, scheduling, site selection, obtaining the necessary permits, transportation coordination and parking, set up a speaker or entertainer, set decoration, catering, event security and emergency plans. This activity success certainly broad impact and increase the power of tourism appeal in Merauke.

\section{CONCLUSION}

Strategic management can be enforced on the whole organization (private, state or independent) on a wide range activity. Marind Cultural Arts Festival in 2016 improving where society are applied the right strategic management on the implementation through festival so that it makes this festival goes accordance with strategic planning, operational planning and implementation of appropriate targeted. Then it is time for the local Government giving Merauke society or stakeholders competent in the implementation of events or festival area, so that the desire goals and objectives are achieved accordance with the city vision and mission.

\section{REFERENCES}

[1] Batbual, Agapitus. 9 september 2015. Ndambu di Pulau Kimaam, Perayaan Unjuk Hasil Alam. Mongabai.co.id.

[2] David, Fred R. 2008. Strategic Management: Concept \& Case 12 th Edition. Prentice Hall, Inc.

[3] Putri, Ratih Dewi Pratama Adyka. 2015. Pengembangan Manajemen Strategi Festival Seni Surabaya, Institut Seni Indonesia Yogyakarta.

[4] Rob Harris and Johnny, Allen, Lindfield. 2002. Handbook Regional Event Management. N.S.W.: Australian Centre for Event Management, University of Technology.

[5] Saputro, Johan. 2014. Perencanaan Penyelenggaraan Festival Kesenian Yogyakarta (FKY) sebagai Media Komunikasi Identitas Yogyakarta sebagai KotaBbudaya, Universitas Islam Kalijaya Yogyakarta. 